that it can be gradually diminished before films are shown, thus avoiding the painful effects on the eyes of suddenly switching on and off the full illumination. The illumination in corridors should have a value intermediate between that outside and the theatre. An illumination on the floor of 0.5 foot candles would be sufficient. Here, again, all lights should be shaded. The convention employed in the early tube days, namely, that going towards green lights leads to safety or exits, and that departing from red lights indicates the same procedure, might be adopted."

N. Bishop Harman (Brit. Med. Jl., February 17 and March 10, 1917), while he admits that it is difficult to give figures as regards evil effects upon'children's eyes directly due to the cinematograph, considers that the increasing number of children that fail to pass the visual tests at the schools, and yet are found to have no eye defect, and are able to pass the test at a later period, may have something to do with excessive indulgence in "picture shows." Tibbles (Brit. Med. Jl., March 3, 1917) agrees that fatigue caused by the glare and flicker of the cinematograph may be responsible for the class of case described by Harman. W. B. I. Pollock (Glas. Med. Jl., April, 1917) believes that by frequent attendance at cinematograph displays, younger children (from 4 to 8 years of age) develop a tendency to convergent squint, in the absence of errors of refraction, and older ones congestion of the optic nerve and complaints of eye-strain. He therefore objects to the introduction of the cinematograph into school-teaching, except at rare intervals.

\title{
Tennent Chair of Ophthalmology at Glasgow
}

Dr. Gavin P. Tennent, a well-known general practitioner in Glasgow, who died in 1913 , left the large sum of $£ 25,000$ in Trust for the formation of the "Tennent Fund." It has now been agreed between the University of Glasgow and the Tennent Trustees, with the approval of the University Committee of the Privy Council, that there shall be in the University of Glasgow a Tennent Chair of Ophthalmology, in connection with the Western Infirmary of Glasgow.

The essential points of the conditions attached to the Professoriate are that the salary shall be $£ 500$ per annum, that the professor "shall not himself be required to give instruction to undergraduate students," but shall apply himself to the promotion of higher studies in ophthalmology and to research, and that the professor shall be allowed to hold office till the end of the academical year in which he shall have completed the sixty-fifth year of his age but no longer, and shall thereupon be entitled to a pension.

An important reservation is that the first professor shall not be 
appointed until the University Court shall intimate to the Board of seven curators, in whom the patronage is to be vested, that the necessary buildings are erected and ready for occupation.

\section{The Oxford Ophthalmological Congress}

The Oxford Ophthalmological Congress held its eighth annual meeting at Oxford on July 12 and 13 last.

Members assembled on the evening of July 11 at Keble College, where, as in former years, accommodation had been kindly provided by the college authorities.

The Congress was again indebted to Professor Arthur Thomson for permission to conduct its proceedings in the Department of Human Anatomy in the University Museum.

The meeting, which was well attended, was opened with a short address of welcome by the Master, Mr. Sydney Stephenson.

The subject chosen for discussion was "The Correction of Errors of Refraction," the openers being Lieut.-Colonel Robert H. Elliot and Mr. Ernest Clarke.

Dr. George M. Gould (Atlantic City, N.J., U.S.A.), who had accepted the invitation of the council to open the discussion, was unavoidably prevented from attending owing to the serious illness of Mrs. Gould, but the manuscript of his address was read.

The following took part in the discussion:- Sir Anderson Critchett, Bt., C.V.O. (London), Mr. Harrison Butler (Leamington Spa), Dr. J. Gray Clegg (Manchester), Captain R. J. Coulter (Newport, Mon.) Dr. F. W. Edridge-Green (London), Miss Marion Gilchrist (Glasgow), Dr. D. V. Giri (Southampton), Dr. T. Eustace Harwood (London), Mr. John Hern (Darlington), Dr. George Young (Colchester), Dr. H. M. Traquair (Edinburgh), Lieut.-Colonel Hanford McKee, C.M.G. (Montreal) and Mr. S. Johnson Taylor (Norwich).

The Council having decided that a lecture shall be delivered annually at the meeting in memory of the late Mr. Robert Walter Doyne, founder and first Master of the Congress, had invited Dr. Gould to become the first lecturer, and the invitation having been accepted, Dr. Gould's enforced absence was the more to be regretted.

The medal which the Council has decided shall be presented to the lecturer will accordingly be sent to Dr. Gould.

The morning of the second day was devoted to papers and demonstrations, etc. A paper by Dr. Edridge-Green (London) on the relationship of the theory of vision to ophthalmology* was discussed by Lieut.-Colonel Elliot, Mr. Harrison Butler, Dr. Stewart Barrie, Dr. Traquair and Mr. Hern. Dr. George Young gave an 